\title{
The Ross procedure: Time to reevaluate the guidelines
}

\author{
Martin Misfeld, MD, PhD, and Michael A. Borger, MD, PhD
}

\author{
From the University Clinic of Cardiac Surgery, Heart Center, University of Leipzig, Leipzig, Germany. \\ Disclosures: Authors have nothing to disclose with regard to commercial support. \\ Received for publication July 9, 2018; accepted for publication July 10, 2018; available ahead of print Aug 11, \\ 2018. \\ Address for reprints: Michael A. Borger, MD, PhD, Heart Center, University of Leipzig, Struempellstrasse 39, \\ 04289 Leipzig, Germany (E-mail: michael.borger@helios-kliniken.de). \\ J Thorac Cardiovasc Surg 2019;157:211-2 \\ $0022-5223 / \$ 36.00$ \\ Copyright (c) 2018 by The American Association for Thoracic Surgery \\ https://doi.org/10.1016/j.jtcvs.2018.07.014
}

In this issue of the Journal, David and colleagues ${ }^{1}$ provide another piece of convincing evidence that the Ross procedure is an excellent therapeutic option for selected patients requiring aortic valve replacement (AVR) surgery. In their series of 212 patients with a median age of 34 years, the cumulative probability of freedom from Ross-related reoperation at 20 years was a superb $85.9 \%$. The probability of autograft regurgitation at 20 years was $13.0 \%$, and that of homograft dysfunction was $19.7 \%$. The independent predictors of autograft failure were older age at operation, male sex, preoperative aortic valve regurgitation, and time since operation. Furthermore, no operative deaths or serious adverse events were observed in the $14 \%$ of patients who required valve reoperation during follow-up. Such data play a large role in the observation that patients undergoing the Ross procedure at experienced centers have the same life expectancy as age- and sex-matched control subjects from the general population. ${ }^{2,3}$ Recent evidence suggest that patients undergoing the Ross procedure may even have better long-term survival than those undergoing mechanical AVR.

Several important studies have been published in the last few years demonstrating very good to excellent long-term results of the Ross procedure in large series of young adult patients needing AVR. ${ }^{2-5}$ Despite these findings, the Ross operation has not gained widespread acceptance, and published valve guidelines have generally not been supportive of the procedure. The latest American guidelines give a class IIb, level of evidence $\mathrm{C}$ recommendation for the Ross procedure in young patients when vitamin $\mathrm{K}$ anticoagulation is contraindicated or undesirable, ${ }^{6}$ and the most recent European guidelines ${ }^{7}$ do not even mention the Ross operation whatsoever. Both sets of guidelines recommend a mechanical prosthesis for young adults requiring AVR; however, it is specifically this patient population that may benefit the most from a Ross procedure, if performed by experienced hands.

One argument against wider adoption the Ross procedure is the fact that only a few centers have published extensively discussion.

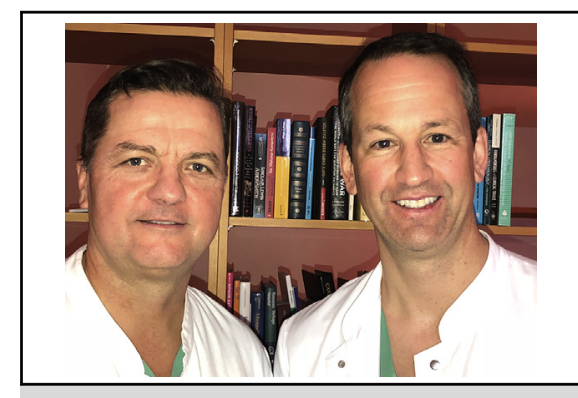

Martin Misfeld, MD, PhD (leff), and Michael A. Borger, $\mathrm{MD}, \mathrm{PhD}$ (right)

\section{Central Message}

The Ross procedure is associated with excellent long-term results in centers of expertise. Future versions of valve guidelines should more strongly recommend this option.

See Article page 201.

on this subject. The same argument can be applied, however, to minimally invasive and robotic mitral valve repair, aortic valve-sparing procedures, and thoracoabdominal aortic repair. Single-center series from a small number of expert surgeons represent the criterion standard against which others should be comparing their results. Whether that means that such procedures should be diminished or neglected by the guidelines writing committees is open to

The recently published low rates of Ross-related reoperations during very long follow-up are summarized in Table 1. This table supplies strong support for the contention that the Ross procedure should be offered to young patients requiring AVR. Long-term freedom from valverelated reoperation rates are comparable to those achieved with a mechanical prosthesis, without any of the risks involved with lifelong anticoagulation.

It should be noted that the previously mentioned results include early experience with the Ross operation in each of the study centers. Further improvements may be expected as knowledge that has been attained with time is applied. For example, there is now sufficient evidence that reoperation rates after the Ross procedure are higher among patients with connective tissue disorders, those with isolated aortic regurgitation, and those who do not undergo some form of aortic root stabilization.

In conclusion, the article by David and colleagues ${ }^{1}$ supplies further evidence that the Ross procedure is an excellent alternative for young adults requiring AVR in centers 
TABLE 1. Late results of the Ross operation

\begin{tabular}{|c|c|c|c|c|}
\hline \multirow[b]{2}{*}{ Study } & \multirow[b]{2}{*}{$\mathbf{N}$} & \multirow[b]{2}{*}{ Age (y) } & \multicolumn{2}{|c|}{ 20-y freedom from Ross-related reoperation } \\
\hline & & & Autograft $(95 \%$ CI $)$ & Homograft $(95 \%$ CI $)$ \\
\hline David et $\mathrm{al}^{1}$ & 212 & 34 (median), 28-41 (IQR) & $88.5 \%(82.0-92.8)$ & $91.8 \%(85.3-95.4)$ \\
\hline Sievers et $\mathrm{al}^{2}$ & 630 & $44.7 \pm 11.9($ mean $\pm \mathrm{SD})$ & $89.8 \%(84.3-95.7)$ & $91.0 \%(86.3-96.0)$ \\
\hline Skillington et $\mathrm{al}^{3}$ & 322 & 39.5 (mean), 15-63 (range) & $96 \%(92-98)^{*}$ & - \\
\hline Martin et $\mathrm{al}^{5}$ & 310 & $40.8 \pm 10.6($ mean $\pm \mathrm{SD})$ & $76.1 \%(66.8-83.2)$ & $82.6 \%(73.2-88.9)$ \\
\hline
\end{tabular}

$C I$, Confidence interval; $I Q R$, interquartile range; $S D$, standard deviation. *Results are at 18 years.

of expertise. It is time for the guidelines to reflect the evergrowing body of evidence supporting this operation.

\section{References}

1. David TE, Ouzounian M, David CM, Lafreniere-Roula M, Manlhiot C. Late results of the Ross procedure. J Thorac Cardiovasc Surg. 2019;157: 201-8.

2. Sievers HH, Stierle U, Petersen M, Klotz S, Richardt D, Diwoky M, et al. Valve performance classification in 630 subcoronary Ross patients over 22 years. $J$ Thorac Cardiovasc Surg. 2018;156:79-86.e2.

3. Skillington PD, Mohkles MM, Takkenberg JJM, Larobina M, O'Keefe M, Wynne R, et al. The Ross procedure using autologous support of the pulmonary autograft: techniques and late results. J Thorac Cardiovasc Surg. 2015;149(2 Suppl):S46-52.
4. Buratto E, Shi WY, Wynne R, Poh CL, Larobina M, O'Keefe M, et al. Improved survival after the Ross procedure compared with mechanical aortic valve replacement. J Am Coll Cardiol. 2018;71:1337-44.

5. Martin E, Mohammadi S, Jacques F, Kalavrouziotis D, Voisine P, Doyle D, et al. Clinical outcomes following the Ross procedure in adults: a 25-year longitudinal study. J Am Coll Cardiol. 2017;70:1890-9.

6. Nishimura RA, Otto CM, Bonow RO, Carabello BA, Erwin JP III, Fleisher LA, et al. 2017 AHA/ACC focused update of the 2014 AHA/ACC guidelines for the management of patients with valvular heart disease: a report of the American College of Cardiology/American Heart Association task force on clinical practice guidelines. J Am Coll Cardiol. 2017;70:252-89.

7. Falk V, Baumgartner H, Bax JJ, De Bonis M, Hamm C, Holm PJ, et al; ESC Scientific Document Group. 2017 ESC/EACTS guidelines for the management of valvular heart disease. Eur J Cardiothorac Surg. 2017;52:616-64. Erratum in: Eur J Cardiothorac Surg. 2017;52:832. 